\section{Essential oil composition and isolation of free- radical-scavenging phenolic glycosides from the aerial parts of Ajuga chamaepitys growing in Iran}

\author{
Abbas Delazar, ${ }^{1}$ Mohammad-reza Delnavazi, ${ }^{2}$ Narges Yassa, ${ }^{2}$ \\ Shiva parkhideh, ${ }^{1}$ Nima Delazar, ${ }^{1}$ Lutfun Nahar, ${ }^{3}$ Satyajit D. \\ Sarker $^{4 *}$
}

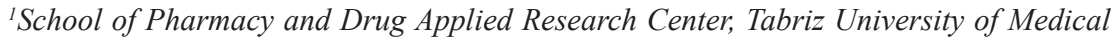
Sciences, Iran,

${ }^{2}$ Department of Pharmacognosy, Faculty of Pharmacy, Tehran University of Medical Sciences, Iran,

${ }^{3}$ Leicester School of Pharmacy, De Montfort University, The Gateway, Leicester, England, UK,

${ }^{4}$ Department of Pharmacy, School of Applied Sciences, University of Wolverhampton, England, UK.

\begin{abstract}
From the methanolic extract of the aerial parts of Ajuga chamaepitys (L.) Schreb., Lamiaceae, one of the Iranian medicinal plants, the phenylethanoid glycoside, acteoside, and two flavone glycosides, chrysoeriol 7-Oglucopyranoside (3'-methoxy-luteolin 7-O-glucopyranoside) and apigenin 7-Orhamnopyranoside, were isolated by a combination of solid-phase extraction (SPE) and preparative reversed-phase high-performance liquid chromatography (prep-RP-HPLC) methods. Structures of the isolated compounds were elucidated by spectroscopic means. The free-radical-scavenging properties of the extracts, fractions and isolated compounds were determined by the 2,2-diphenyl-1picryl-hydrazyl (DPPH) assay. While among the extracts, the $\mathrm{MeOH}$ extract showed the highest level of free-radical-scavenging activity (RC50 $1.15 \times 10^{-}$ $\mathrm{mg} / \mathrm{mL}$ ), chrysoeriol 7-O-glucopyranoside was the most active (RC50 3.00 $\times 10^{-3} \mathrm{mg} / \mathrm{mL}$ ) among the isolated compounds. The GC-MS and the GC-FID analyses revealed $\alpha$-pinene (23.66\%), $\beta$-pinene (9.33\%), 1-octen-3-ol (9.72\%), $\beta$-phellandrene $(8.70 \%)$ and germacrene-D $(7.92 \%)$ as the major components of the essential oils derived from the aerial parts of this plant. The presence of phenolic glycosides and the $\alpha$ - and $\beta$-pinene-rich essential oils in $A$. chamaepitys may provide some rationale for the traditional medicinal uses of this species in Iran.
\end{abstract} Brazilian Journal of Pharmacognosy 22(2): 299-305, Mar./Apr. 2012

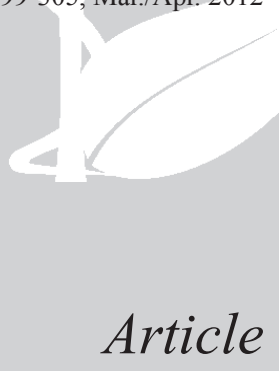

Received 25 Jun 2011

Accepted 9 Aug 2011

Available online 23 Nov 2011
Revista Brasileira de Farmacognosia

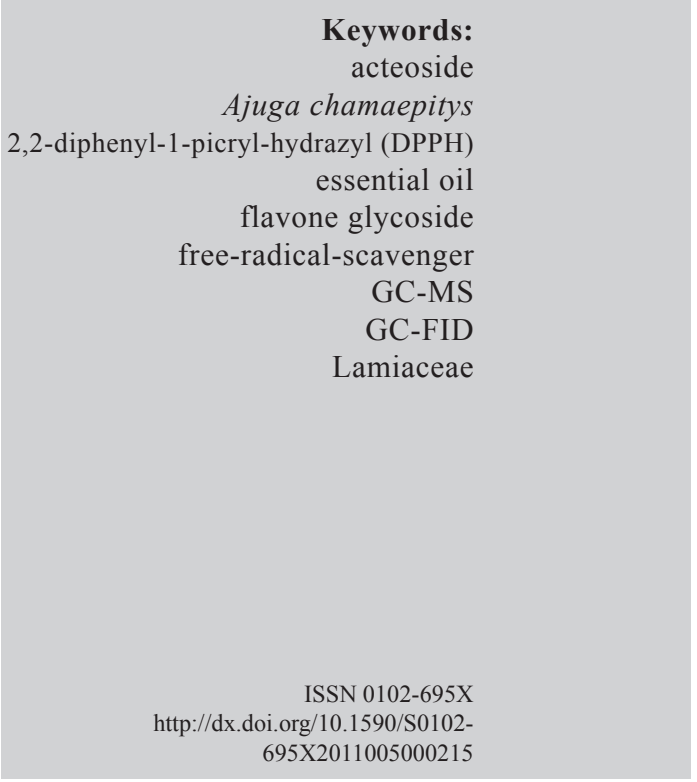

Keywords: acteoside Ajuga chamaepitys essential oil flavone glycoside avenger GC-MS GC-FID Lamiaceae http://dx.doi.org/10.1590/S0102$695 \times 2011005000215$

\section{Introduction}

The genus Ajuga L. of the family Lamiaceae (alt. Labiateae) comprises over 300 species with many subspecies and varieties, which are distributed all over the world (Israili \& Lyoussi, 2009). Ajuga chamaepitys (L.) Schreb. (common name: "yellow bugle") is one of the five Ajuga species from the flora of Iran. This species, which has been mentioned as the name of "Kamaphytus" in the old texts of traditional medicine, is one of the species of the Lamiaceae that has been used in the Iranian traditional medicine for centuries (Naghibi et al., 2009). This plant has long been used as a diuretic, tonic, emmenagogue agent and menser remover, and for wound-healing and perspiration (Ulukanli et al., 2005).
Applications of this species to treat scorpion and snake bites, hemorrhoids, stomachache, jaundice, inflammatory diseases, such as gout and joint pains, and common colds have also been well documented (Zargari, 1997; Ulukanli et al., 2005; Israili \& Lyoussi, 2009; Naghibi et al., 2009). Antimicrobial, antiviral and antifeedant and cytotoxic properties of various extracts of this plant have been reported (Kutas \& Nadasy, 2005; Akçin et al., 2006; Orhan et al., 2009; Turkoglu et al., 2010). Previous phytochemical investigations on this plant revealed the presence of cloredan and neocloredan diterpenes in the aerial parts, and $\beta$-pinene and germacrene-D as the major components of the essential oils (Hernandez et al., 1980; Camps et al., 1984, 1987; Boneva et al., 1990; Baser et al., 1999; Azizan et al., 2002; Velasco-Negueruela 
et al., 2004). In continuation of our phytochemical and pharmacological studies on the medicinal plants of the Iranian flora (Delazar et al., 2004, 2006, 2007, 2009, 2010a,b; 2011a,b; Babaei et al., 2008; Nazemieyh et al., 2008a,b, 2011; Nazifi et al., 2008; Razvi et al., 2008, 2011; Modaressi et al., 2009; Asnaashari et al., 2010), we now report on the isolation, identification and free-radicalscavenging properties of three phenolic glycosides (1-3), and the composition of the essential oils of the aerial parts of Ajuga chamaepitys (L.) Schreb. growing in Iran.

\section{Material and Methods}

\section{General}

NMR spectra were obtained using a Bruker Spectrospin 200 and an AMX300 NMR-spectrometers. UV-visible spectra were recorded using a Shimadzu-1600 spectrophotometer. Preparative HPLC was conducted on Shimadzu -10A prep-HPLC coupled with SPDM photo diode array detector (detection at 220 and $280 \mathrm{~nm}$ ).

\section{Plant material}

Aerial parts of Ajuga chamaepitys (L.) Schreb., Lamiaceae, were collected during the flowering stage from the "Mishodagh" mountains located in Shabestar (East-Azarbaijan province, Iran) in May 2008. A voucher specimen (TUM-ADE-0318) for this collection has been deposited at the Herbarium of the Faculty of Pharmacy, Tabriz University of Medical Sciences, Tabriz, Iran.

\section{Extraction}

Dried and ground aerial parts of $A$. chamaepitys $(100 \mathrm{~g})$ were successively Soxhlet-extracted using n-hexane, dichloromethane (DCM) and methanol $(\mathrm{MeOH})(1.5 \mathrm{~L}$ each). All these extracts were separately concentrated under vacuum by rotary evaporator not exceeding the temperature of $50{ }^{\circ} \mathrm{C}$.

\section{Essential oils extraction}

The essential oils of the aerial parts $(50 \mathrm{~g}$ in $400 \mathrm{~mL}$ of $\mathrm{H}_{2} \mathrm{O}$ ) were obtained by hydro-distillation method using the Clevenger apparatus for about $4 \mathrm{~h}$, dried over anhydrous sodium sulfate and stored at $4{ }^{\circ} \mathrm{C}$ until analysis.

\section{Fractionation of the methanolic extract}

Dried methanolic extract $(2 \mathrm{~g} \times 2)$ was fractionated by solid-phase-extraction on Sep-Pak $\left(\mathrm{C}_{18}, 10 \mathrm{~g}\right.$ cartridge $)$ using a step gradient of methanolwater mixture $(10: 90,20: 80,40: 60,80: 20$ and 100:0).
All fractions were dried using a rotary evaporator at a temperature not exceeding $50{ }^{\circ} \mathrm{C}$.

\section{Isolation of phenolic glycosides}

The Sep-Pak fraction of 40\% MeOH-water (590 $\mathrm{mg}$ ) was analyzed by prep-RP- HPLC (Dr Maisch ODS preparative column $10 \mu \mathrm{m}, 250 \mathrm{~mm}$ x $20 \mathrm{~mm}$, solvent system: linear gradient $0-30 \mathrm{~min}, 15-25 \%$ acetonitrile $(\mathrm{ACN})$ in water; isocratic $25 \% \mathrm{ACN}$ in water during 30-35 min; linear gradient 35-40 $\mathrm{min}, 25-5 \% \mathrm{ACN}$ in water; linear gradient 40-65 $\mathrm{min}, 5-100 \% \mathrm{ACN}$ in water; flow rate $8 \mathrm{~mL} / \mathrm{min}$; detection at: 220 and $280 \mathrm{~nm}$ ) to yield the phenylethanoid glycoside, acteoside (1, 30.0 $\mathrm{mg}, \mathrm{tR}=27.55 \mathrm{~min})$. Similarly, the prep-RP- HPLC analysis of the fraction $60 \%(70 \mathrm{mg})$, using the mobile phase: linear gradient $0-57 \mathrm{~min}, 26-32 \% \mathrm{ACN}$ in water; isocratic $32 \% \mathrm{ACN}$ in water during 57-60 min; linear gradient $60-75 \mathrm{~min}, 32-100 \% \mathrm{ACN}$ in water; flow rate $8 \mathrm{~mL} / \mathrm{min}$; detection at: 220 and $280 \mathrm{~nm}$, resulted in the isolation of chrysoeriol 7-O-glucopyranoside $(2,3.5 \mathrm{mg}$; $\left.t_{\mathrm{R}}=16.4 \mathrm{~min}\right)$ and apigenin 7-O-rhamnopyranoside (3, $\left.3 \mathrm{mg} ; t_{\mathrm{R}}=29.58 \mathrm{~min}\right)$. The structures of these phenolic glycosides were determined by $\mathrm{UV}$ in $\mathrm{MeOH}$ and using various shift reagents (Mabry et al., 1970), and NMR $\left({ }^{1} \mathrm{H}\right.$ and ${ }^{13} \mathrm{C}$ ) spectral analyses as well as by comparison with respective published data.

\section{GC-MS and GC-FID analyses}

The essential oils were analyzed using a Shimadzu GCMS-QP5050A gas chromatograph-mass spectrometer (GC-MS) fitted with a fused methyl silicon DB-5 column (60 m x $0.25 \mathrm{~mm}$ i.d., $0.25 \mu \mathrm{m}$ film thickness). Helium was used as carrier gas at a flow rate of $0.9 \mathrm{~mL} / \mathrm{min}$. The oven temperature was kept at $50{ }^{\circ} \mathrm{C}$ for $2 \mathrm{~min}$, and programmed to rise to $230{ }^{\circ} \mathrm{C}$ at a rate of $2{ }^{\circ} \mathrm{C} / \mathrm{min}$ and then kept constant for $8 \mathrm{~min}$. The injector temperature was 250 ${ }^{\circ} \mathrm{C}$ and split ratio was adjusted at 1:51. The mass spectral (MS) data were obtained at the following conditions: ionization potential $70 \mathrm{eV}$; ion source temperature $200{ }^{\circ} \mathrm{C}$; quadrupole temperature $100{ }^{\circ} \mathrm{C}$; solvent delay $3 \mathrm{~min}$; EM voltage 3000 volts. Identification of compounds was based on direct comparison of the Kovats indices (K. I.) and MS data with those for standard compounds, and computer matching with the NIST NBS54K Library, as well as by comparison (Massada, 1976; Adams, 2004).

For quantitation (area \%), the GC analyses were also performed on an Agilent 6890 series apparatus fitted with a FID detector. The FID detector temperature was $300{ }^{\circ} \mathrm{C}$. To obtain the same elution order as with GC-MS, simultaneous auto-injection was performed on a duplicate of the same column applying the same operational conditions. Relative percentage amounts of the separated compounds were calculated from FID chromatograms. 
Free-radical-scavenging activity: the 2,2-diphenyl-1picrylhydrazyl (DPPH) assay

The free-radical-scavenging effect of the extracts, fractions and isolated compounds was assessed using the 2,2-diphenyl-1-picrylhydrazyl (DPPH) assay (Kumarasamy et al., 2002, 2007). DPPH was obtained from Fluka Chemie AG, Bucks and a solution of DPPH $(0.08 \mathrm{mg} / \mathrm{mL})$ in methanol was used. Dilutions were made to obtain concentrations of $5 \times 10^{-1}, 2.5 \times 10^{-1}, 1.25 \times 10^{-1}$, $6.25 \times 10^{-2}, \quad 3.13 \times 10^{-2}$ and $1.56 \times 10^{-2} \mathrm{mg} / \mathrm{mL}$. Diluted solutions $(1 \mathrm{~mL}$ each) were mixed with DPPH solution $(1 \mathrm{~mL})$ and allowed to stand for $30 \mathrm{~min}$ for any reaction to take place. The UV absorbance was recorded at 517 $\mathrm{nm}$. The experiment was performed in triplicate and the average absorption was noted for each concentration.

\section{Results and Discussion}

Solid-phase extraction (SPE) of the $\mathrm{MeOH}$ extract of the aerial parts of Ajuga chamaepitys (L.) Schreb., Lamkiaceae, followed by reversed-phase preparative HPLC analyses of the SPE fractions ( $40 \%$ and $60 \%$ aqueous $\mathrm{MeOH}$ fractions) resulted in the isolation three free-radical-scavenging phenolic glycosides (1-3). Isolated glycosides were identified unequivocally as the phenylethanoid glycoside, acteoside (1; Delazar et al., 2005; Nazemiyeh et al., 2008c), and two flavone glycosides, chrysoeriol 7-O-glucopyranoside (2; Mabry et al., 1970; Wagner et al., 1976; Wenkert \& Gottlieb, 1977; Zhang \& Li, 2008; Zhao et al., 2009; Zhou et al., 2009) and apigenin 7-O-rhamnopyranoside (3; Mabry et al., 1970; Wagner et al., 1976; Wenkert \& Gottlieb, 1977; Iwashina \& Matsumoto, 1994; Chunsriimyatav et al., 2009), by extensive UV spectroscopic analyses using various shift reagents (Mabry et al., 1970) and NMR analyses (Tables 1 and 2). All spectroscopic data were comparable with respective published data. This is the first report on the occurrence of compounds 1-3 in the species of Ajuga chamaepitys (L.) Schreb., Lamiaceae, and to the best of our knowledge, none of these phenolic glycosides has ever been reported from the genus Ajuga. However, other flavonoids have previously been reported from only a few other species of the genus Ajuga, e.g. A. reptans and A. remota (Terahara et al., 2001; Manguro et al., 2007).

The free-radical-scavenging activity of the extracts, SPE fractions and isolated glycosides (1-3) were determined by the 2,2-diphenyl-1-picryl-hydrazyl (DPPH) free-radical-scavenging assay (Kumarasamy et al., 2002, 2007) (Table 3). The $\mathrm{MeOH}$ extract showed the highest level of activity with a RC50 value of $1.15 \times 10^{-1} \mathrm{mg} / \mathrm{mL}$ among all extracts, and most of its activity was contributed by the SPE fractions of $40 \%$ and $60 \%$ aq. $\mathrm{MeOH}$ fractions, and the compounds responsible for this activity were phenolic glycosides (1-3), which displayed significant free-radical-scavenging properties with the RC50 values ranging from $8.5 \times 10^{-3}$ to $3.0 \times 10^{-3} \mathrm{mg} / \mathrm{mL}$ (Table 3 ), quite comparable to that of the positive control quercetin (RC50 $2.5 \times 10^{-3} \mathrm{mg} / \mathrm{mL}$ ). While to the best of our knowledge, this is the first report on the free-radical-scavenging property of $A$. chamaepitys growing in Iran, subspecies euphratica from this species that grows in Turkey has recently been shown to possess antioxidant properties (Torkoglu et al., 2010).

Table 1. ' $\mathrm{H}$ NMR (200 MHz, $\mathrm{CD}_{3} \mathrm{OD}$, coupling constant $\mathrm{J}$ in $\mathrm{Hz}$ in parentheses) and ${ }^{13} \mathrm{C} \mathrm{NMR}\left(50 \mathrm{MHz}, \mathrm{CD}_{3} \mathrm{OD}\right)$ data of acteoside (1).

\begin{tabular}{lll}
\hline \multirow{2}{*}{ Carbon number } & \multicolumn{2}{c}{ Compound $\mathbf{~}$} \\
\cline { 2 - 3 } & $\delta_{\mathrm{H}}(\mathrm{ppm})$ & $\delta_{\mathrm{C}}(\mathrm{ppm})$ \\
\hline
\end{tabular}

Aglycone (3-methoxy-4-hydroxyphenylethyl) moiety

3

4

5

6

7

8

Aglycone (trans-3,4-dimethoxycinnamoyl) moiety

1 ,

2'

3

4

5

6

7

8 ,

9'

$\begin{array}{cc}6.73 \mathrm{~d}(1.5) & 116.1 \\ - & 145.1 \\ - & 143.6 \\ 6.71 \mathrm{~d}(8.0) & 115.3 \\ 6.60 \mathrm{dd}(1.5,8.0) & 120.3 \\ 2.82 \mathrm{t}(5.4) & 35.6 \\ 3.8-4.1^{*} & 71.3\end{array}$

Glucosyl moiety

1 ",

2 "

3"

4"

5 "

$6 "$

-
$7.29 \mathrm{~d}(2.0)$
-
-
$6.81 \mathrm{~d}(8.0)$
$6.99 \mathrm{dd}(2.0,8.0)$
$7.63 \mathrm{~d}(16.0)$
$6.30 \mathrm{~d}(16.0)$

126.6

113.6

145.9

148.8

115.5

122.3

147.1

115.1

167.3

$4.41 \mathrm{~d}(7.8)$

103.2

3.2-3.8*

75.1

3.2-3.8*

80.7

3.2-3.8*

69.4

3.2-3.8*

75.2

3.2-3.8*

61.3

Rhamnosyl moiety

1 ",

$5.2 \mathrm{~d}(1.5)$

102.1

2",

3.2-3.8*

71.3

3 "'

4 ",

3.2-3.8*

71.1

3.2-3.8*

72.8

5 ,"

3.2-3.8*

69.6

$6 "$,

$1.12 \mathrm{~d}(6.1)$

17.5

*Overlapped peaks 
Table 2. ${ }^{1} \mathrm{H}$ NMR $\left(200 \mathrm{MHz}, \mathrm{CD}_{3} \mathrm{OD}\right.$, coupling constant $\mathrm{J}$ in $\mathrm{Hz}$ in parentheses) and ${ }^{13} \mathrm{C} \mathrm{NMR}\left(50 \mathrm{MHz}, \mathrm{CD}_{3} \mathrm{OD}\right)$ data of chrysoeriol 7-O-glucopyranoside (2) and apigenin 7-Orhamnopyranoside (3).

\begin{tabular}{|c|c|c|c|c|}
\hline \multirow{2}{*}{$\begin{array}{l}\text { Carbon } \\
\text { number }\end{array}$} & \multicolumn{2}{|c|}{.$\delta_{\mathrm{H}}(\mathrm{ppm})$} & \multicolumn{2}{|c|}{.$\delta_{\mathrm{C}}(\mathrm{ppm})$} \\
\hline & 2 & 3 & 2 & 3 \\
\hline \multicolumn{5}{|c|}{ Aglycone (flavone) moiety } \\
\hline 2 & - & - & 162.8 & 162.2 \\
\hline 3 & $6.75 \mathrm{~s}$ & $6.61 \mathrm{~s}$ & 102.6 & 102.3 \\
\hline 4 & - & - & 182.0 & 182.9 \\
\hline 5 & - & - & 158.1 & 158.4 \\
\hline 6 & $6.55 \mathrm{~d}(2.1)$ & $6.32 \mathrm{br} \mathrm{s}$ & 99.5 & 100.1 \\
\hline 7 & - & - & 165.2 & 165.8 \\
\hline 8 & $6.90 \mathrm{~d}(2.1)$ & $6.43 \mathrm{br} \mathrm{s}$ & 95.1 & 95.0 \\
\hline 9 & & & 161.3 & 161.6 \\
\hline 10 & & & 106.4 & 106.2 \\
\hline 1 ' & - & - & 121.3 & 121.7 \\
\hline 2 ' & $7.56 \mathrm{~d}(2.0)$ & $7.86 \mathrm{~d}(7.9)$ & 110.3 & 128.6 \\
\hline 3 , & - & $6.94 \mathrm{~d}(7.9)$ & 148.0 & 116.1 \\
\hline 4 ' & - & - & 150.1 & 161.6 \\
\hline 5 & $6.98 \mathrm{~d}(8.4)$ & $6.94 \mathrm{~d}(7.9)$ & 115.8 & 115.8 \\
\hline $6^{\prime}$ & $7.60 \mathrm{dd}(8.4,2)$ & $7.86 \mathrm{~d}(7.9)$ & 120.6 & 128.3 \\
\hline $\mathrm{OMe}$ & $4.00 \mathrm{~s}$ & - & 58.7 & - \\
\hline \multicolumn{5}{|c|}{ Glycosyl moiety } \\
\hline $1 "$ & $5.52 \mathrm{~d}(7)$ & $5.41 \mathrm{br} \mathrm{s}$ & 103.0 & 103.7 \\
\hline $2 "$ & $3.30-4.00 *$ & $3.30-4.00^{*}$ & 73.7 & 71.9 \\
\hline $3 "$ & $3.30-4.00 *$ & $3.30-4.00^{*}$ & 77.3 & 71.3 \\
\hline $4 "$ & $3.30-4.00^{*}$ & $3.30-4.00^{*}$ & 70.2 & 73.4 \\
\hline $5 "$ & $3.30-4.00 *$ & $3.30-4.00 *$ & 76.8 & 69.5 \\
\hline $6 "$ & $3.30-4.00^{*}$ & $1.21 \mathrm{~d}(7)$ & 61.4 & 17.4 \\
\hline
\end{tabular}

*Overlapped peaks.

The air-dried aerial parts of $A$. chamaepitys provided $0.1 \%$ pale yellow essential oils. The GC-MS and GC-FID analyses of the essential oils led to the separation of 25 peaks accounting for $94 \%$ of the total oils. Out of 25 separated peaks, 22 components $(\sim 88 \%)$ could be identified (Table 4). The majority of components present in the oils were hydrocarbon monoterpenes constituting about $49 \%$ of the total oils. There were also significant amounts $(\sim 19 \%)$ of hydrocarbon sesquiterpenes present in the oils. The absence of any oxygenated mono- or sesquiterpenes in the oils was particularly noticeable. Among the identified components, $\alpha$-pinene was the major component representing about $24 \%$ of the total oils. $\beta$-Pinene (9.33\%), 1-octen-3-ol (9.72\%), $\beta$-phellandrene $(9.70 \%)$ and germacrene D $(7.92 \%)$ were four other noteworthy components which were present in significant amounts. The composition of the essential oils of the aerial parts of the subspecies and varieties of $A$. chamaepitys varies quite significantly in different regions. For example, in A. chamaepitys ssp. chamaepitys growing in Spain, $\gamma$-muurolene $(40.3 \%)$, limonene (20.5\%) and germacrene B (7.8\%) were identified as the major components (Velasco-Negueruela et al., 2004), which were significantly different from the composition of $A$. chamaepitys as stated above. However, the presence of $\alpha$ - and $\beta$-pinene in significant amounts appears to be common in the subspecies and varieties of this species that grow in north of Iran (Gilan province) and Turkey (Baser et al., 1999; Azizan et al., 2002). The predominance of $\alpha$ - and $\beta$-pinene in the essential oils of other Ajuga species has also been noted (Javidnia et al., 2010; Mohammadhosseini et al., 2011).

Table 3. Free-radical-scavenging activities of the extracts, fractions and isolated compounds (1-3) from the aerial parts of Ajuga chamaepitys (L.) Schreb.in the DPPH assay.

\begin{tabular}{|c|c|}
\hline Extracts/fractions/compounds & RC50 value $(\mathrm{mg} / \mathrm{mL})$ \\
\hline$n$-Hexane extract & $14.5 \times 10^{-1}$ \\
\hline DCM extract & $6.34 \times 10^{-1}$ \\
\hline $\mathrm{MeOH}$ extract & $1.15 \times 10^{-1}$ \\
\hline SPE fraction $10 \% \mathrm{MeOH}-\mathrm{H}_{2} \mathrm{O}$ & $4.33 \times 10^{-1}$ \\
\hline SPE fraction $20 \% \mathrm{MeOH}-\mathrm{H}_{2} \mathrm{O}$ & $1.45 \times 10^{-1}$ \\
\hline SPE fraction $40 \% \mathrm{MeOH}-\mathrm{H}_{2} \mathrm{O}$ & $1.50 \times 10^{-2}$ \\
\hline SPE fraction $60 \% \mathrm{MeOH}-\mathrm{H}_{2} \mathrm{O}$ & $6.80 \times 10^{-2}$ \\
\hline SPE fraction $80 \% \mathrm{MeOH}-\mathrm{H}_{2} \mathrm{O}$ & $1.42 \times 10^{-1}$ \\
\hline SPE fraction $100 \% \mathrm{MeOH}$ & $2.36 \times 10^{-1}$ \\
\hline Acteoside (1) & $8.50 \times 10^{-3}$ \\
\hline Chrysoeriol 7-O-glucopyranoside (2) & $3.00 \times 10^{-3}$ \\
\hline Apigenin 7-O-rhamnopyranoside (3) & $4.80 \times 10^{-3}$ \\
\hline Quercetin (positive control) & $2.50 \times 10^{-3}$ \\
\hline
\end{tabular}

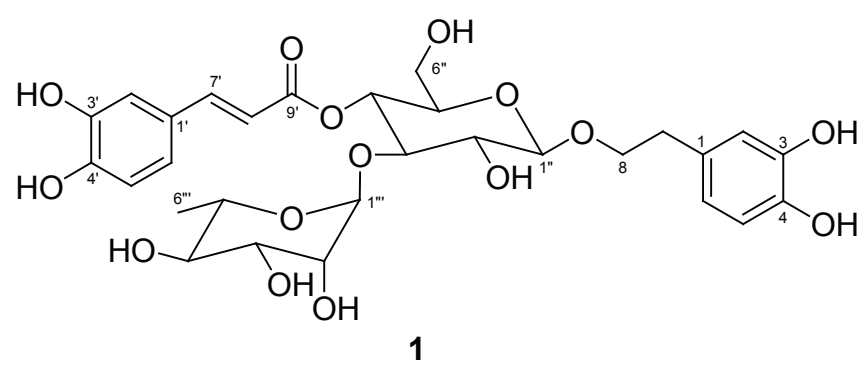<smiles>[R20]c1cc(O)c2c(=O)cc(-c3ccc(O)c([R1])c3)oc2c1</smiles>

$2 \mathrm{R}=$ glucosyl; $\mathrm{R}_{1}=\mathrm{OMe}$ $3 \mathrm{R}=$ rhamnosyl; $\mathrm{R}_{1}=\mathrm{H}$ 
Table 4. GC-MS and GC-FID data of the essential oils of the aerial parts of Ajuga chamaepitys (L.) Schreb.

\begin{tabular}{|c|c|c|c|c|c|}
\hline No. & Compounds & $\begin{array}{c}\text { Real \% } \\
\text { area }\end{array}$ & K. I. & $\begin{array}{l}\text { Molecular } \\
\text { mass }\end{array}$ & $\begin{array}{l}\text { Molecular } \\
\text { formula }\end{array}$ \\
\hline 1 & $\alpha$-Pinene & 23.66 & 931 & 136 & $\mathrm{C}_{10} \mathrm{H}_{16}$ \\
\hline 2 & 1-Hepten-3-one & 3.04 & 948 & 126 & $\mathrm{C}_{8} \mathrm{H}_{14} \mathrm{O}$ \\
\hline 3 & $\beta$-Pinene & 9.33 & 971 & 136 & $\mathrm{C}_{10} \mathrm{H}_{16}$ \\
\hline 4 & 1-Octen-3-ol & 9.72 & 971 & 128 & $\mathrm{C}_{8} \mathrm{H}_{16} \mathrm{O}$ \\
\hline 5 & $\beta$-Myrcene & 1.83 & 987 & 136 & $\mathrm{C}_{10} \mathrm{H}_{16}$ \\
\hline 6 & $\beta$-Phellandrene & 8.70 & 1022 & 136 & $\mathrm{C}_{10} \mathrm{H}_{16}$ \\
\hline 7 & $\delta$-Carene & 2.56 & 1023 & 136 & $\mathrm{C}_{10} \mathrm{H}_{16}$ \\
\hline 8 & $\beta$-Ocimene & 1.20 & 1042 & 136 & $\mathrm{C}_{10} \mathrm{H}_{16}$ \\
\hline 9 & $\alpha$-Terpinolene & 1.29 & 1081 & 136 & $\mathrm{C}_{10} \mathrm{H}_{16}$ \\
\hline 10 & $\beta$-Damascenone & 3.35 & 1377 & 190 & $\mathrm{C}_{10} \mathrm{H}_{18} \mathrm{O}$ \\
\hline 11 & Unidentified & 1.15 & 1379 & 136 & - \\
\hline 12 & $\alpha$-Bourbonene & 1.10 & 1381 & 204 & $\mathrm{C}_{15} \mathrm{H}_{24}$ \\
\hline 13 & trans- $\alpha$-Bergamoptene & 1.82 & 1328 & 204 & $\mathrm{C}_{15} \mathrm{H}_{24}$ \\
\hline 14 & Aromadendrene & 3.91 & 1433 & 204 & $\mathrm{C}_{15} \mathrm{H}_{24}$ \\
\hline 15 & $\alpha$-Humulene & 2.81 & 1447 & 204 & $\mathrm{C}_{15} \mathrm{H}_{24}$ \\
\hline 16 & Unidentified & 1.92 & 1461 & 136 & - \\
\hline 17 & Germacrene D & 7.92 & 1477 & 204 & $\mathrm{C}_{15} \mathrm{H}_{24}$ \\
\hline 18 & $\beta$-Curcumene & 0.60 & 1508 & 204 & $\mathrm{C}_{15} \mathrm{H}_{24}$ \\
\hline 19 & Junipene & 1.28 & 1652 & 204 & $\mathrm{C}_{15} \mathrm{H}_{24}$ \\
\hline 20 & Unidentified & 2.95 & 1716 & 220 & - \\
\hline 21 & Hexadecanoic acid & 3.21 & 1951 & 256 & $\mathrm{C}_{16} \mathrm{H}_{32} \mathrm{O}_{2}$ \\
\hline 22 & Eicosane & 1.05 & 2000 & 282 & $\mathrm{C}_{20} \mathrm{H}_{42}$ \\
\hline 23 & Hexacosane & 1.78 & 2600 & 366 & $\mathrm{C}_{26} \mathrm{H}_{54}$ \\
\hline 24 & Octacosane & 2.55 & 2800 & 394 & $\mathrm{C}_{28} \mathrm{H}_{58}$ \\
\hline \multirow[t]{7}{*}{25} & Nonacosane & 1.27 & 2900 & 408 & $\mathrm{C}_{29} \mathrm{H}_{60}$ \\
\hline & $\begin{array}{l}\text { Hydrocarbon } \\
\text { monoterpenes }\end{array}$ & 48.57 & & & \\
\hline & $\begin{array}{l}\text { Hydrocarbon } \\
\text { sesquiterpenes }\end{array}$ & 19.44 & & & \\
\hline & $\begin{array}{l}\text { Hydrocarbon } \\
\text { nonterpenes }\end{array}$ & 6.65 & & & \\
\hline & $\begin{array}{l}\text { Oxygenated } \\
\text { nonterpenes }\end{array}$ & 19.32 & & & \\
\hline & Unidentified & 6.02 & & & \\
\hline & Total identified & 87.96 & & & \\
\hline
\end{tabular}

The phytochemical investigation of the aerial parts of $A$. chamaepitys has demonstrated that this plant is a good source of phenolic glycosides with significant free-radical-scavenging property, and the essential oils of the aerial parts predominantly contain hydrocarbon monoterpenes. While flavonoids and phenyl propanoid glycosides (e.g. acteoside, 1) are well known biologically active natural products, plant essential oils possess, among others, notable antimicrobial properties. Thus, it is reasonable to assume, yet not being too much speculative, that the presence of phenolic glycosides 1-3, and the $\alpha-$ and $\beta$-pinene-rich essential oils in $A$. chamaepitys may provide some rationale for the traditional medicinal uses of this species in Iran.

\section{References}

Adams RP 2004. Identification of Essential Oil Component by Gas Chromatography/Quadrupole Mass Spectroscopy. Allured Publishing Corporation, Illinois, USA.

Akçin ÖE, Senel G, Akçin Y 2006. The morphological and anatomical properties of Ajuga reptans L. and Ajuga chamaepitys (L.) Schreber subsp. Chia (Schreber) Arcangeli var. Chia (Lamiaceae) taxa. Pak J Biol Sci 9: 289-293.

Asnaashari S, Delazar A, Alipour SS, Nahar L, Williams AS, Pasdaran A, Mojarab, M., Fatih-Azad F, Sarker SD 2010. Chemical composition, free-radical-scavenging and insecticidal activities of the aerial parts of Stachys byzantina. Arch Biol Sci 62: 653-662.

Azizan J, Fallah-Bagher-Shaidaei H, Kefayati H 2002. Chemical constituents of the essential oil of Ajuga chamaepitys growing in Iran. J Essential Oil Res 14: 344-345.

Babaei H, Sadeghpour O, Nahar L, Delazar A, Nazemiyeh H, Mansouri MR, Poursaeid N, Asnaashari S, Moghadam SB, Sarker SD 2008. Antioxidant and vasorelaxant activities of flavonoids from Amygdalus lycioides. Turkish J Biol 32: 203-208.

Baser KHC, Erdemgil Z, Özek T, Demirci B 1999. Composition of essential oils from two varieties of Ajuga chamaepitys subsp. chia from Turkey. J Essential Oil Res 11: 203205.

Boneva IM, Mikhova BP, Malakov PY, Papanov GY, Duddeck H, Spassov SL 1990. Neo-clerodane diterpenoids from Ajuga chamaepitys. Phytochemistry 29: 2931-2933.

Camps F, Coll J, Dargallo O 1984. Neo-clerodane diterpenoids from Ajuga chamaepitys. Phytochemistry 23: 25772579.

Camps F, Coll J, Dargallo O, Rius J, Miravitlles C 1987. Clerodane diterpenoids from Teucrium and Ajuga plants. Phytochemistry 26: 1475-9.

Chunsriimyatav G, Hoza I, Valasek P, Skrovankova S, Banzragch D, Tsevegsuren N 2009. Anticancer activity of lignan from the aerial parts of Saussurea salicifolia (L.) DC. Czech J Food Scs 27: S256-S258.

Delazar A, Byres M, Gibbons S, Kumarasamy Y, Modarresi M, Nahar L, Sarker SD 2004. Iridoid glycosides from Eremostachys glabra. J Nat Prod 67: 1584-1587.

Delazar A, Gibbons S, Kumarasamy Y, Nahar L, Shoeb M, Sarker SD 2005. Antioxidant phenylethanoid glycosides from the rhizomes of Eremostachys glabra (Lamiaceaea). Biochem Syst Ecol 33: 87-90.

Delazar A, Biglari F, Esnaashari S, Nazemiyeh H, Talebpour AH, Nahar L, Sarker SD 2006. GC-MS analysis of the essential oils, and the isolation of phenylpropanoid derivatives from the aerial parts of Pimpinella aurea. Phytochemistry 67: 2176-2181. 
Delazar A, Naseri M, Nahar L, Moghadam S, Esnaashari S, Nazemiyeh H, Sarker SD 2007. GC-MS analysis and antioxidant activities of essential oils of two cultivated Artemisia species. Chem Nat Compds 43: 112-114.

Delazar A, Nazifi E, Movafeghi A, Nahar L, Nazemiyeh H, Moghadam SB, Asnaashari S, Sarker SD 2009. GC-MS analyses of Ornithogalum procerum. DARU 17: 33-36.

Delazar A, Khodaie L, Afsar J, Nahar L, Sarker SD 2010a. Isolation and free-radical-scavenging properties of cyanidin 3-Oglycosides from the fruits of Ribes biebersteinii Berl. Acta Pharmaceutica 60: 1-11.

Delazar A, Nazifi E, Movafeghi A, Nazemiyeh H, Hemmati S, Nahar L, Sarker SD 2010b. Analyses of phytosterols and free radical scavengers from the bulbs of Ornithogalum cuspidatum Bertol. BLACPMA 9: 87-92.

Delazar A, Delnavazi MR, Nahar L, Moghadam SB, Mojarab M, Gupta A, Williamns A, Rahman MM, Sarker SD 2011a. Lavandulifolioside B: a new phenylethanoid glycoside from the aerial parts of Stachys lavandulifolia Vahl. Nat Prod Res 25: 8-16.

Delazar A, Bahmani M, Hekmat-Shoar H, Tabatabaei-Raisi A, Asnaashari S, Nahar L, Sarker SD 2011b. Effect of altitude, temperature and soil on essential oil production in Thymus fedtschenkoi flowers in Osko and surrounding areas in Iran. J Essential Oil Bear Pl 14: 23-29.

Hernandez A, Pascual C, Sanz J, Rodríguez B 1980. Diterpenoids from Ajuga chamaepitys: two neoclerodane derivatives. Phytochemistry 21: 29092911.

Israili ZH, Lyoussi B 2009. Ethnopharmacology of the plants of genus Ajuga. Pak J Pharm Sci 22: 425-462.

Iwashina T, Matsumoto S 1994. Flavonoid variation and evolution in Asplenium normale and related species (Aspleniaceae). J Plant Res 107: 275-282.

Javidnia K, Miri R, Soltani M, Khosravi AR 2010. Chemical constituents of the essential oil of Ajuga austro-iranica Rech. f. (Lamiaceae) from Iran. $J$ Essential Oil Res 22: 392-394.

Kumarasamy Y, Fergusson M, Nahar L, Sarker SD 2002. Biological activity of moschamindole from Centaurea moschata. Pharm Biol 40: 307-310.

Kumarasamy Y, Byres M, Cox PJ, Jaspars M, Nahar L, Sarker SD 2007. Screening seeds of some Scottish plants for free-radical scavenging activity. Phytother Res 21: 615621.

Kutas J, Nádasy M 2005. Antifeedant effects of several plant extracts on Colorado potato beetle larvae. Acta Phytopathologica et Entomologica Hungarica 40: 355365.

Mabry TJ, Markham KR, Thomas MB 1970. The Systematic Identification of Flavonoids. Springer-Verlag, New York.

Masnguro LOA, Ogur JA, Okora DM, Wagai SO, Lemmen P 2007. Further flavonol and iridoid glycosides from Ajuga remota aerial parts. J Asian Nat Pro Res 9: 617-
629.

Massada Y 1976. Analysis of essential oil by gas chromatography and mass spectrometry. John Wiley and Sons, New York, USA.

Modaressi M, Delazar A, Nazemiyeh H, Fathu-Azad E, Smith E, Rahman MM, Gibbons S, Nahar L, Sarker SD 2009. Antibacterial iridoid glucosides from Eremostachys laciniata. Phytother Res 23: 99-103.

Mohammadhosseini M, Abbas P, Zamani HA, Hashem A 2011. Chemical composition of the essential oil from aerial parts of Ajuga chamaecistus Ging. subsp Scopria in Brackish regions of Iran. J Essential Oil Bear Pl 14: 101-105.

Naghibi F, Mosaddegh M, Mohammadi Motamed S, Ghorbani A 2009. Labiatae family in folk medicine in Iran: from ethnobotany to pharmacology. Iranian J Pharm Res 4: 63-79.

Nazemiyeh H, Delazar A, Ghahramani M-A, Talebpour A-H, Nahar L, Sarker SD 2008a. Phenolic glycosides from Phlomis lanceolata (Lamiaceae). Nat Prod Commun 3: 53-56.

Nazemiyeh H, Bahadori F, Delazar A, Ay M., Topcu G, Kolak U, Nahar L, Majinda RRT, Sarker SD 2008b. Antioxidant phenolic compounds from the leaves of Erica arborea (Ericaceae). Nat Prod Res 22: 1385-1392.

Nazemiyeh H, Rahman MM, Gibbons S, Nahar L, Delazar A, Ghahramani M-A, Talebpour A-H, Sarker SD 2008c. Assessment of the antibacterial activity of phenylethanoid glycosides from Phlomis lanceolata against multipledrug-resistant strains of Staphylococcus aureus. J Nat Med 62: 91-92.

Nazemiyeh H, Latifpoor F, Delazar A, Razavi SM, Esna-Ashari S, Kasebi N, Talebpour A-H, Nahar L, Sarker SD 2011. Chemical composition, free-radical-scavenging and antibacterial properties of the essential oil of a citronellol producing new chemotype of Thymus pubescens Boiss. \& Kotschy ex Celak. Records of Nat Prod 5: 184-192.

Nazifi E, Delazar A, Movafeghi A, Nazemiyeh H, Nahar L, Sarker SD 2008. GC-MS analysis of the dichloromethane extract of the bulbs of Ornithogalum cuspidatum Bert. (Family: Liliaceae) from Iran. Records of Nat Prods 2: 94-99.

Orhan I, Deliorman-Orhan D, Özçelik B 2009. Antiviral activity and cytotoxicity of the lipophilic extracts of various edible plants and their fatty acids. Food Chem 115: 701-705.

Razvi SM, Nazemiyeh H, Hajiboland R, Kumarasamy Y, Delazar A, Nahar L, Sarker SD 2008. Coumarins from the aerial parts of Prangos uloptera (Apiaceae). Rev Bras Farmacogn 18: 1-5.

Razavi SM, Nazemiyeh H, Delazar A, Asnaashari S, Hajiboland R, Sarker SD, Omidi Y 2011. Chemical variation of the essential oil of Prangos uloptera DC. at different stages of growth. Nat Prod Res 25: 663-668.

Terahara N, Callebaut A, Ohba R, Nagata T, OhnishiKameyama M, Suzuki M 2001. Acylated anthocyanidin 
Essential oil composition and isolation of free-radical-scavenging phenolic glycosides from the aerial parts of Ajuga chamaepitys growing in Iran

3-sophoroside-5-glucosides from Ajuga reptans flowers and the corresponding cell cultures. Phytochemistry 58 : 493-500.

Turkoglu S, Turkoglu I, Kahyaoglu M, Celik S 2010. Determination of antimicrobial and antioxidant activities of Turkish endemic Ajuga chamaepitys (L.) Schreber subsp. euphratica P. H. Davis (Lamiaceae). $J$ Med Plant Res 4: 1369-1367.

Ulukanli Z, Ulukanli S, Ozbay H, Ilcim A, Tuzcu M 2005. Antimicrobial activities of some plants from the Eastern Anatolia region of Turkey. Pharm Biol 43: 334-339.

Velasco-Negueruela A, Pérez-Alonso MJ, Palá-Paúl J, Iñigo A, Sanz J 2004. Volatile constituents of the essential oil of Ajuga chamaepitys (L.) Schreber. ssp. chamaepitys from Spain. J Essential Oil Res 16: 372-373.

Wagner H, Chari VM, Sonnenbichler J 1976. C-13 NMR spectra of natural flavonoids. Tetrahedron Lett 21: 1799-1802.

Wenkert E, Gottlieb HE 1977. C-13 Nuclear Magnetic Resonance spectroscopy of naturally occurring substances 49. C-13 Nuclear Magnetic Resonance spectroscopy of flavonoid and isoflavonoid compounds. Phytochemistry 16: 1811-1816.

Zargari A 1997. Medicinal plants. Tehran University of Medical Sciences, Tehran.

Zgang P-F, Li C 2008. Flavones from flowers of Paulownia fortunei. Zhongguo Zhong Yao Za Zhi 33: 2629-2632.

Zhao SJ, Han M, Han ZM, Li YY, Yang LM 2009. Separation and identification of flavonoids from Smilacina japonica by high speed counter-current chromatography. Chinese J Anal Cehm 37: 1354-8.

Zhou Y, Wang W, Tang L, Yan X-G, Shi L-Y, Wang Y-Q, Feng B-M 2009. Lignan and flavonoid glycosides from Urtica laetevirens Maxim. J Nat Med 63: 100-101.

\section{*Correspondence}

\section{Satyajit D. Sarker}

Department of Pharmacy, School of Applied Sciences, University of Wolverhampton

MA Building, Room: 106, Wulfruna Street, Wolverhampton WV1 1LY, England, UK

s.sarker@wlv.ac.uk

Tel. +44 (0) 1902322578 